UDC 78.03(477)«1921/1939»

DOI: 10.24919/2519-058x.12.177543

\title{
Andriy ZHYVYUK
}

PhD (History), Associate Professor, Professor at Stepan Demianchuk International University of Economics and Humanities, 4 Stepan Demianchuk Street, Rivne, Ukraine, postal code 33000 (derzhy60@gmail.com)

ORCID: https://orcid.org/0000-0002-9031-880X

\section{Ruslana DAVYDYUK}

PhD hab. (History), Associate Professor, Professor, Rivne State Humanities University, 12 Stepan Bandera Street, Rivne, Ukraine, postal code 33000 (davrus63@gmail.com)

ORCID: https://orcid.org/0000-0003-0485-5121

\section{Андрій ЖИВ'ЮК}

кандидат історичних наук, дочент, професор Міжнародного економіко-гуманітарного університету імені академіка Степана Дем'янчука, вул. Степана Дем'янчука, 4, Рівне, Україна, індекс 33000 (derzhy60@gmail.com)

\section{Руслана ДАВИДЮК}

доктор історичних наук, дочент, професор Рівненського державного гуманітарного університету, вул. Степана Бандери, 12, Рівне, Україна, індекс 33000 (davrus63@gmail.com)

Бібліографічний опис статті: Zhyvyuk, A. \& Davydyuk, R. (2019). Naddnipryanska Ukraine emigrants musical activities in Volyn Voivodeship. Skhidnoievropeiskyi Istorychnyi Visnyk [East European Historical Bulletin], 12, 116-125. doi: 10.24919/2519-058x.12.177543

\section{NADDNIPRYANSKA UKRAINE EMIGRANTS MUSICAL ACTIVITIES IN VOLYN VOIVODESHIP}

Summary. The purpose of the research is to analyse the role and place of Ukrainian political emigrants, Naddnipryanska Ukraine (Dnieper Ukraine) natives, in the musical culture development on Volyn Voivodeship territory based on the archival sources and the interwar periodicals (1921-1939). The methodology of the research is based on the science, historicism, verification principles. In the course of study the historical science methods have been used such as search, identification and systematization of the historical material, obtained from the archival documents and the press sources and with the further criticism of the other methods have been applied the historical-comparative, the historical-typological, the historical-chronological, the historical-geographical and other research methods. The scientific novelty of the article is based on the introduction into the scientific circulation the Sectoral State Archives of the Foreign Intelligence Service of Ukraine deciphered archival documents, archival-criminal cases from the Sectoral State Archives of the Security Service of Ukraine, Rivne region State Archive, other archival materials, the interwar periodical, which helped to depict Naddnipryanskykh political emigrants influences on the musical culture development of the interwar Volyn, in some places to trace their fate. It is proved that, despite the everyday difficulties, the emigrants stood out from the rest in social and socio-cultural activities, their musical activity was not only a way of earning money, but also an opportunity for creative self-realization, which helped them in adaptation to the new conditions. 
Conclusions. The Ukrainian Revolution figures of the 1917 - 1921, who were forced to emigrate to Poland and settled down in Volyn Voivodeship, intensified the musical life in the region. They were the folk choirs founders, moreover, they organized tours, worked as church choirs conductors, founded artistic societies, joined the search campaign for the musical and ethnographic materials for the purpose of their artistic elaboration by amateur choirs and theaters, scientific publications. At this time, the following musicians developed their talent: Mykhailo Telezhinskyi, Oleksa Kolisnichenko, Sozont Kalmutskyi, Serhiy Kozytskyi, Hanna Bilohub. The Polish authorities control was manifested in censoring the repertoire, interfering with the conductors and singers, trying to use the artistic sphere in order to spread the pro-government policy. The choral art development, the concerts and competitions organizations, the ethnographic song material collection, enriched the cultural life of the region.

Key words: Volyn Voivodeship, musical culture, folk choirs, Naddnipryanska Ukraine, Ukrainian political emigrants, «Volyn experiment».

\section{МУЗИЧНА ДІЯЛЬНІСТЬ ЕМІГРАНТІВ ІЗ НАДДНІПРЯНСЬКОЇ УКРАЇНИ У ВОЛИНСЬКОМУ ВОСВОДСТВІ}

Анотація. Мета дослідження. На основі архівних джерел та міжвоєнної періодики проаналізувати роль і місце діячів української політичної еміграції, уродженців Наддніпрянської України, у розвитку музичної культури на території Волинського воєводства (1921 - 1939). Методологія дослідження трунтується на принциипах науковості, історизму, верифікації. У ході дослідження використовувались такі методи історичної науки, як пошук, ідентифікація і систематизачія історичного матеріалу, отриманого з архівних документів і пресових джерел, з подальшою його критикою шляхом застосування історико-порівняльного, історико-типологічного, історико-хронологічного, історико-географічного та іниих досліднииьких методів. Наукова новизна статті полягає у введенні до наукового обігу розсекречених архівних документів Галузевого державного архіву Служби зовнішньої розвідки України, архівно-кримінальних справ з Галузевого держсавного архіву Служби безпеки України, Державного архіву Рівненської області, інших архівних матеріалів, міжвоєнної періодики, що дало можливість показати вплив наддніпрянських політичних емігрантів на розвиток музичної культури міжвоєнної Волині, подекуди прослідкувати їх подальшу долю. Доведено, щьо, незважаючи на побутові труднощі, емігранти вирізнялися громадською та соиіокультурною активністю, їхня музична діяльність була не лише способом заробітку, а й можливістю творчої самореалізаиії, допомагала в адаптаиії до нових умов. Висновки. Діячі Української революиії 1917 - 1921 рр., які вимушено емігрували на територію Польщі і оселилися у Волинському воєводстві, активізували музичне життя у регіоні. Вони були засновниками народних хорів, організовували гастрольні тури, праиювали диригентами церковних хорів, створювали мистецькі товариства, долучалися до пошуку музично-етнографічних матеріалів з метою їхнього художнього опраџювання аматорськими хорами й театрами, наукового видання. У ией час розвинувся талант музикантів Михайла Тележинського, Олекси Колісниченка, Созонта Кальмуцького, Сергія Козиџького, Ганни Білогуб. Контроль польської влади виявився у цензуруванні репертуару, втручанні у роботу диригентів $i$ співаків, намаганні використати мистецьку сферу для поширення проурядової політики. Розвиток хорового мистецтва, проведення концертів, конкурсів, збирання пісенного етнографічного матеріалу збагачувало культурне життя краю.

Ключові слова: Волинське воєводство, музична культура, народні хори, Наддніпрянська Україна, українські політичні емігранти, «волинський експеримент».

The problem statement. After the Ukrainian National-Democratic Revolution defeat in 1917 - 1921, thousands of its members found themselves in the political exile in Poland. With their artistic experience, they became fully involved in cultural and artistic life in Volyn region. Despite the Polish authorities control, the Ukrainian emigrants initiated the folk and church choirs formation, collected and processed the musical and ethnographic materials.

The purpose of the article is to analyze the Ukrainian political emigrants contribution to the musical culture deployment in Volyn Voivodeship territory. 
The analysis of recent researches. Numerous Ukrainian scientists were studying musical culture development on Volyn Voivodeship territory and they paid attention to the musical component in particular. The works of the following scientists should be highlighted: Y. Kramar (Kramar, 2015), P. Shymanskyi (Shymanskyi, 2005), N. Nykytiuk (Nykytiuk, 2008), B. Stoliarchuk (Stoliarchuk, 2002) and the others. The scientist R. Davydiuk studied the «Khaty Prosvity» («Houses of Enlightenment») activities, the Ukrainian political emigration public practices in the region (Davydiuk, 2016). The researcher A. Zhyviuk was interested in the Soviet authorities repression against the active participants in the social and cultural life (Zhyviuk, 2011). Despite the modern researchers achievements, the emigrants and the Naddnipryanska Ukraine natives contributions to the musical culture development of Volyn Voivodeship, as well as their fate, have not been studied profoundly and require the thorough analysis and in-depth reflection. In view of this, the archival documents and the materials of the periodicals became the basis for writing the article. Taking everything into consideration, the archival documents and the periodicals' materials of that time were the basis for writing the article

Statement of the basic material. During the interwar period, many Ukrainian National Democratic Revolution participants in 1917 - 1921, having become the political emigrants, found the political shelter in Poland. Despite the authority obstacles and the restrictions, some of them settled down in Volyn Voivodeship, finding themselves in a predominantly Ukrainian-Orthodox environment that greatly facilitated their creative self-realization.

The first attempts of bringing to life the musical work were made in the «Prosvita» society by the choirs creation. There were the adult and children's choirs in Ostroh «Prosvita» society, headed by the former director of the Department of Education of the Ukrainian National Republic (UNR), Mykola Shuhayevskyi. Raising the Ukrainian local population national consciousness, the «Prosvita» society organized holidays dedicated to T. Shevchenko traditionally, which included T. Schevchenko's poetry, poems recitation, choir songs and performances. The holiday dedicated to T. Shevchenko usually ended with the «Testament» («Zapovit») declamation and «Ukraine has not died yet» («Shche ne Vmerla Ukrayiny») the Ukrainian national anthem performance (State Archives of Rivne region (SARR), f. 33, d. 4, c. 3, p. 120). Serhiy Kozytskyi, Moscow Teachers Institute graduate, singing courses under M. Ippolitov-Ivanov guidance, played a prominent role in the musical activity of Ostroh «Prosvita» society (State Archive of the External Intelligence Service of Ukraine (SA EISU), f. 1 , c. 12617 , vol. 5 , p. 222).

The Musical creativity, the performances and the concerts had a dual nature, they were not only a way of spending leisure time, but also a means of earning the living for the military emigrants needs, who in late 1923 founded the labour colonies in Babyn, Shpanov, Tsuman and the others. At Babyn sugar factory, the emigrants organized a theatrical group, a string orchestra (mandolinists and guitarists), a secular and sacred choir (Wiszka, 2004, p. 594). In Tsuman labour colony, a choir was formed under Oleksa Tantsyra, the UNR Army khorunzhyi (cornet) officer supervision (Samoorhanizatsiia, 1926, p. 14-15).

The numerous UNR Army former soldiers worked as the church choirs conductors. In particular, Yakym Bartko, having experience of creating a choir during the revolution in Vinnytsia region, organized the Svyatoblahovishchennya Church choir (Annunciation Church) in Kovel, Vasyl Babichenko - in Mlyn, and Volodymyr Sviderskyi - in Pokrov Church in Kosareve village, Dubenskyi district, Semen Leshchuk - in Mykulychi village, Volodymyrskyi district. Oleksander Ditkevych, Nemesis village teacher, Sarnenskyi district, 
the UNR Army khorunzhyi (cornet) officer headed the «Prostiva» choir and later on served as a priest (Davydiuk, 2016, p. 538-539).

Dmytro Kotko, in the past UNR Army wind orchestras (brass bands) curator, the choir leader in the internment camp, has organized the Ukrainian choir tours in Volyn. The first choir staff was selected from the gifted Naddniprayanska Ukraine music schools former students and graduates. Since 1925, the collective was called «Ukrainian Naddnipryanskyi Choir». The choir had a mixed composition (originally males) and grew to 40 people according to the Polish officials request (Dilo, 1925, p. 2). In autumn 1928, Kotka choir gave several concerts in the Kremenets districts: on the $1^{\text {st }}$ October - in Vyshnivtsi, on the $2^{\text {nd }}-3^{\text {rd }}$ October - in Kremenets, on the $5^{\text {th }}$ October the choir performed in Smyzi, Dubenskyi district (State Archives of Ivano-Frankivsk Region (SAIFR), f 2, d. 1, c. 597, p. 38). Subsequently, the choir collective went through a split up, a difficult period, due to the reorganization the choir raised from ashes and was updated (1935 - 1939).

The bandurist Kost Misevych (a member of the Central Council of Ukraine (Ukrayin'ska Tsentralna Rada), Podilsk Railway commissioner in 1918) toured Poland and performed with his student Dmytryi Gonta and Danylo Shcherbyna. In 1929 K. Misevich settled down in Kremenets region and got married with the singer Margarita Bono (Bzheskyi, 2015, p. 112). He taught his wife how to play bandura, after that they performed in duets in the voivodeship villages, promoting a Ukrainian song. D. Shcherbyna, the former «synyozhupnyk», later on returned to the USSR, where he was arrested. Back in 1924, in a letter to General Y. Tyutyunnyk, he wrote the following: «Here in Volyn the Poles do not give the opportunity not only to work or even live. I crossed the Zbruch river in 1920 as the member of the administrative staff in the Ministry of roads... Accompanied by bandura, I was singing our historical and modern dumy and songs. Of course, most of all Lyakhy (the Poles) suffer from our songs context for the Ukraine's neighbour life. That is why I am not surprised that the «power possessors» hate me (Verstiuk, Skalskyi, Faizulin, 2011, p. 383-384).

After «Prosvita» prohibition during «Volyn experiment» period brought in by Henryk Józewski and, considering the urgent need to fill the created cultural and educational vacuum, the emigrants, along with the voivodeship administration support, initiated the establishment of new, loyal to the authorities, Ukrainian cultural organizations. The musical culture development was an important activity area for these institutions. In 1930, the Ukrainian song amateur society «Rivnenskyi Boyan» appeared in Rivne, which, according to the charter, united the admirers of the secular and ecclesiastical Ukrainian choral art, solo singing. The amateur society planned to organize concerts, vechornytsi (Slavic traditional gatherings with music, songs, jokes and rituals), art evenings, start up the choral courses, etc. (SARR, f. 479, d. 1, c. 1, p. 2), but could not deploy dynamic activity.

In the 30-ies the musical creativity development was accumulated in the «Khaty of Prosvita» («Houses of Enlightenment») in the villages, in cities - in «Ridni Khaty» («Native Home»). The Ukrainian choir performed the rehearsals under Mykhailo Telezhinskyi supervision (a member of the Central Council of Ukraine (Ukrayin'ska Tsentralna Rada), the UNR troops state inspector, the First Ukrainian National Choir conductor), Holy Cross society church choir, Volyn Ukrainian Theatre performed, some courses were conducted for the conductors in «Ridna Khata» («Native Home»), Lutsk (Ridna, 1934, p. 6).

Every single concert or any national feast was initiated by the emigrants and accompanied by music. For instance, the academy in Rivne, dedicated to the memory of those shot near Bazar village, consisted of the memorial service, the special essay, the poems recitation 
the gymnasium choir performance conducted by the UNR Army centurion, S. Kalmutskyi. The Kremenetskyi Ukrainian private gymnasium choir performed Ukrainian songs, the students acted out a fragment of the story «Motrya» written by B. Lepkyi, recited the poems about the hetman, completing the academy in honour of Ivan Mazepa on June 2, 1935. (Akademiia, 1935, p. 6).

In Lutsk Ukrainian Gymnasium, a bandurist group was organized by Modest Levytskyi, the doctor of the institution (the Ukrainian Railways chief sanitary doctor during 1917 - 1918, of the UNR State Center (SC) Health Minister, a writer), who accomplished bandura courses in Czechoslovakia. Hanna Bilohub, the teacher of Lutsk Ukrainian Gymnasium, the UNR Army colonel Dmitry Bilogub's wife, together with whom she was in the internment camp in Wadowice, was Modest Levytskyi's student and follower. H. Bilohub promoted the musical culture, heralded various speeches («Some sketches on bandura and bandura players history»), (Bandura, 1939, p. 5), toured 29 regions of the voivodeship, performed at 70 events (Zahalni, 1939, p. 5).

Volyn Ukrainian Theatre Society (VUTS) united the Ukrainian intelligentsia representatives, who were not indifferent to the theatrical and musical arts in the 1930ies, the meeting of which were held in Lutsk on January 3, 1932 on the statute basis approved in 1931. (State Archive of Volyn region (SAVR), f. 200, d. 1, c. 2, p. 53). It was stated that the society was national and was aimed at «Ukrainian cinema support, arranging performances, concerts, lectures, establishing the drama studios, the music schools, the film studios, the amateur circles support», etc. (Volynske, 1932, p. 1). The Board of Directors consisted mainly of Naddnipryanshchyna Ukraine (the Dnieper Ukraine) natives members: Chairman - Mykola Maslov, Deputy - Oleksandr Kovalevskyi, Treasurer - General Oleksa Almazov (SAVR, f. 200, d. 1, c. 1, p. 7, 16). There was an art and drama section in the society, which consisted of two commissions: the studio commission (prepared performances for different holidays) and the regulative (rehulaminova) commission (worked out the rules of the society). In the future, the VUTS Board included S. Tymoshenko, O. Kovalevskyi, N. Lototskyi, O. Kolisnychenko and the others (Zahalni, 1939, p. 5), four sections appeared: the artistic and dramatic section, the choreography section, the literary-theatrical section, the musical-vocal section (Teatralne, 1939, p. 2). The VUTS branch functioned in Ostroh under Senator Inokentiy Glovatskyi supervision (Filiia, 1932, p. 4). The VUTS authorized representative in Rivne district was Simon Petliura's nephew, Ambassador Stepan Skrypnyk (SARR, f. 479, d. 1, c. 2, p. 7).

With the help and efforts of the following emigrants: Mykola Bahrynivskyi, Danyl Kovpanenko, Ivan Kornoukhov the «Lesya Ukrainka Literary and Art Society" in Rivne was created, registered by the Voivodeship Government in 1927 (December 2) (SARR, f. 30, d. 20, c. 840 , p. 52). The secretary of the company was Serhiy Polikshaya, Vasyl Pavlovskyi was the board of producers member, Petro Zinchenko, an artist was a member of the board, Andriy Dubynovskyi was the director. (SARR, f. 30, d. 18, c. 2125, p. 14). All these figures in the past were the Ukrainian Revolution members and Naddnipryanska Ukraine (Dnieper Ukraine) natives. According to the statute, the «Lesya Ukrainka Literary and Art Society" had to «study and popularize the literature and art among Ukrainian society, to establish the libraries and reading rooms, to organize choirs, orchestras, drama groups, to manage public academies, arrange lectures, drama, music, conducting courses» (SARR, f. 30, d. 20, c. 840, pp. 47-51). However, without the authorities support, it was difficult to implement the outlined plans, so the society work was limited by the performances, evenings that were 
often held in the private premises (SARR, f. 30, d. 20, c. 840, p. 17, 18). In some places there were organized concerts, which protested the «Bilshovyk oppression» against Ukrainians in the USSR» (SARR, f. 33, d. 4, c. 45, p. 26).

According to the correspondence between St. Lyudkevych and S. Skrypnyk, the issue concerning the music school grand opening in Rivne as Lysenko Higher Music Institute branch in Lviv (the last one had 10 branches in Halychyna (Galicia) in 1932), was triggered in 1932 (SARR, f. 479, d. 1, c. 2, pp. 13-14). However, the information on such music school emergence was not found. It is possible that the above-mentioned projects implementation was made impossible because of the «Sokal borderline» policy.

During the interwar period Mykhailo Telezhynskyi's talent developed. He settled down in Volodymyr and headed «Prosvita» society musical and theatrical section, he was also studying the Ukrainian musical folklore history, theory, practice. M. Telezhynskyi's composer work began in 1922 with «Zamochok» Chorus organization, the Liturgy creation continued with the publication in Stanyslaviv «Songs and Entertainment Collections for Children». Volodymyr's «Prosvita» choir founded with his participation, reflected the best church and folk choral performances.

In the second half of the XXth century M. Telezhynskyi's work as a critic publicist was in the prime of life. He prepared an article commemorating the 100th anniversary of the Ukrainian folk songs collection publication, written by M. Maksymovych (1927), the book «K. Stetsenko - Ukrainian Composer (relating to the Ukrainian song history)», an essay dedicated to M. Leontovych (Ukrainska, 1927, p. 3), edited «Volyn Ukrainian Folk Songs Collection» (Ukrainska, 1934, p. 4). In 1929 he held the position of Holy Cross Choir Regent in Lutsk, and the following year became the Ukrainian folk choirs inspector at the school curatorium. The composer developed the theory of the choral affairs and began conducting the regular conductor courses.

M. Telezhynskyi prepared the Ukrainian «People's Choirs and Orchestras» Charter, which was intended to spread the pro-government ideology, to cooperate with the «Prosvita» society and «Ridni Khaty» («Native Homes»). According to the charter, the choirs were divided into mixed choirs (soprano, viola, tenor, bass), male choirs (the $1^{\text {st }}$ and the $2^{\text {nd }}$ tenors and the $1^{\text {st }}$ and the $2^{\text {nd }}$ bass), female choirs (the $1^{\text {st }}$ and the $2^{\text {nd }}$ soprano and the $1-2^{\text {nd }}$ and the $2^{\text {nd }}$ alt) or 3 voices. Although the programme document emphasized that the competence of «folk choirs did not include matters of a political nature», only the members of the progovernment party Volyn Ukrainian Association (VUA) could join the choir (Ukrainski, 1931, p. 4). Therefore, it is apparent that the artistic sphere was influenced by the pro-government ideology and the Ukrainian-Polish cooperation idea, which was tolerated by the authorities.

In February 1930 a three-day course which dealt with the Ukrainian folk song staging for Volyn «People's Choirs» conductors was held in the «Ridna Khata» («Native Home») premises, and was attended by 48 listeners. M. Telezhynskyi conducted lectures in Ukrainian language at the courses, provided people with some folk songs, vesnyanky (Ukrainian folk song dedicated to spring and springtime work), and dancing (tanok) staging samples (Kursy, 1930, p. 4). On May 13, 1934, Volodymyr district choirs contest began with M. Telezhynskyi's report on the Ukrainian songs, 5 groups and 150 singers wearing national Ukrainian costumes took part in the above-mentioned contest (Konkurs, 1934, p. 2). On February 15, 1938, Lutsk district «Provita Khaty» («Houses of Enlightenment») choirs contest took place. The choirs performed Ukrainian songs by M. Lysenko, O. Koshytsya, M. Leontovych. According to the researchers, there were 250 singers performing in the national costumes, who filled up the 
stage and all stairs in the hall, which created Ukrainian cultural life elevation atmosphere, later on called the «Volyn Renaissance» (Shymanskyi, 2005, p. 3). In the 30-ies the composer's achievements were supplemented with the dozens of choral arrangements, a collection of 160 Ukrainian folk songs.

Oleksa Kolisnichenko, VUT conductor and Sozont Kalmutskyi, Rivne High School Choir Head were the renowned musicians and popularizers of the Ukrainian culture. The choir, headed by O. Kolisnichenko, participated in the funeral services and events held by the Ukrainian public in Lutsk. In 1927 - 1928, the choir, under S. Kalmutskyi's conductor supervision, toured Germany (Ukrainskyi, 1927, p. 3). In 1934, the School District Curatorium of Extracurricular Education Department announced a competition for the Ukrainian folk songs collection in Volyn Voivodeship territory, which was aimed at finding the musical and ethnographic materials for their further artistic elaboration by amateur choirs and theaters, as well as the scientific publication. There were collected 305 folk songs with the help of local teachers and choirmasters, in particular S. Kalmutskyi recorded and submitted 24 songs for the competition (Lukaniuk (ed.), 2015, p. 14).

Serhiy Kozytskyi, a church choir conductor, collected the song folklore, the carols. During the musical processing of the folk songs of Volyn, Polissya, Kholmshchyna, the musician maintained the authenticity of their performance. The composer recorded and decoded more than 100 songs of the winter cycle, put works of T. Shevchenko on the music, founded the ensemble of folk instruments and the secular semi-professional choir. The Church and Enlightenment Choirs, founded by S. Kozytskyi, promoted the folklore, the works by Ukrainian classics (Stoliarchuk, 2002, p. 92).

The famous musicians did not stand apart from the public life. Yakym Bartko was the secretary of the branch of the Ukrainian Central Committee (UCC) in Kovel, Oleksa Tantsyra headed the branch of the UCC in Tsuman, Mykhailo Telyezhynskyi worked as a commissioner of the UCC in Volodymyr-Volynskyi, Sozont Kalmutskyi belonged to Rivne branch of UCC, Oleksa Kolisnychenko - to Lutsk branch of UCC. Those three personalities were actively involved in the work of the VUO (Davydiuk, 2016, p. 245, 248).

The Ambassador to the Polish Sejm Sergei Kozytskyi, who lived in the village of Mykhalkivtsi, had other political interests: he was a supporter of the «Selsouz» Union, later the «Selrob», and after the split he became one of the leaders of the «Selrob-Right Faction» (SA EISU, f. 1, c. 12617, vol. 3, p. 105). His wife's family lived in the Soviet territory, and the ambassador himself was in orbit of the interests of the Bilshovyk special services, who characterized him as an «intelligent and wise man, competent, politically active» (SA EISU, f. 1, c. 12617, vol. 6, p. 34). The Counselor of the USSR in Warsaw M. Lebedynets involved S. Kozytskyi in collecting the materials on the state of Ukrainian schooling in Poland (Soliar, 2009, p. 64). The ambassador was arrested several times by the Polish police for his political and public activities. In 1924, he was sentenced to a year in prison, only on the appeal, he was released on bail. In 1928 and 1930, he was imprisoned for the electional campaigning. After his last arrest, S. Kozytskyi stopped practicing politics (SA EISU, f. 1, c. 12617, vol. 7, p. 199). He gave up teaching and served as a cantor in the villages of Zdolbuniv Povit. It should be noted that in 1922 he passed the exams at Volyn Consistory as a priest (SARR, f. 485 , d. 1 , c. 101 , p. 275 v.).

In general, the interwar period is marked by the development of the choral art, the foundation of choirs, the concerts, the contests, and the collection of the ethnographic material that positively influenced the cultural life of the region. Against the background of 
such changes, the Polish authorities controlled the repertoire, the work of conductors and singers, trying to use the artistic sphere to realize the plans to spread the pro-governmental ideology (SARR, f. 30, d. 20, c. 309, pp. 13-15).

After the establishment of the Bilshovyk power in Western Volyn in September 1939, the political expatriates, such as «the Petliurivtsi», «the enemies of the people», came under the control of the bodies of the People's Commissariat of Internal Affairs (NKVD). Further their fate was different: some were able to leave the territory, which allowed them to save the lives (D. Kovpanenko, S. Poliksha, M. Bahrynivskyi, etc.), the others - were subjected to repression. (Zhyviuk, 2011, p. 29). In 1939, M. Telezhznskyi was arrested: according to some documents, he was killed while trying to escape during the convoy, and according to the others, he was shot in prison. There were arrested the Board members of WUTT: M. Maslov died in exile in Kazakhstan in 1942, the fate of O. Kovalevskyi and I. Hlovatskyi remains unknown, they are likely to have died in Bykivnia (SARR, f. P-2771, d. 2, c. 4253, p. 34; SARR, f. P-2771, d. 2, c. 3662, p. 17; Sectoral State Archive of the Security Service of Ukraine (SSA SSU, Kyiv), f. 13, d. 55, c. 305, p. 30, 71). S. Kozytskyi died in January 1941 at Ostroh Hospital (Denysiuk, 2000, p. 267). Dmytro, the bandurist's husband, Hanna Bilohub, was captured by the NKVD in 1945 as a soldier in the Ukrainian Insurgent Army. Hanna, after the Second World War, changed her name, worked as a teacher, founded a bandura band in Ternopil region (Zheplynskyi). O. Tantsura was arrested in 1945 (SSA SSU, Lutsk), f. П., c. 7291, p. 45).

Conclusions. Thus, the political emigrants, being in the territory of Volyn Voivodeship, fully joined the cultural life in its various forms, participated in the creation of the choirs, the amateur circles, the organized contests, the concerts, the courses, thus uniting the scattered masses in a conscious public collective. Initially, they realized their artistic talents and skills in the «Enlightenment», which was the driving force behind the development of the region. After its ban, they worked in «Enlightenment Houses», «Native Houses», spread the Ukrainian song, developed the choral art. The foundation and the spread of the folk choirs in the villages and towns of Western Volyn was called the «Volyn Renaissance». In the 30-ies the development of the artistic life was taken care of by the emigrants of VUTT, «Lesya Ukrainka Literary and Art Society». Despite the control of the Polish authorities over the repertoire, the involvement of the conductors and singers, the efforts to use the artistic sphere to implement the plans for promoting the pro-government policy, the Ukrainian political emigrants contributed to the development of music, song and ethnographic creativity in the interwar Volyn. With the advent of the Soviet power, many cultural figures were subjected to repression; a further investigation is needed to find out the fate of some of them.

Acknowledgments. We would like to thank the staff of the archival institutions whose documents were used in the article. We are also thankful to the members of the editorial board for the advice, given during the preparation of the article for printing.

Funding. The authors received no financial support for the research, authorship, and/or publication of this article.

\section{BIBLIOGRAPHY}

Akademiia (1935). Akademiia na chest hetmana Ivana Mazepy [The Academy in Honor of Hetman Ivan Mazepa]. Ukrainska nyva, 27-28, 6 lypnia, 6. [in Ukrainian].

Bandura (1939). Bandura [Bandura]. Volynske slovo, 4, 2 liutoho, 5. [in Ukrainian].

Bzheskyi, R. (2015). Prysiaha u sobori [The Oath in the Cathedral]. Siverianskyi litopys, 3, 111-121. [in Ukrainian]. 
Verstiuk, V., Skalskyi, V., Faizulin, Ya. (Uporiad.) (2011). Yurii Tiutiunnyk: vid «Dviiky» do HPU: dokumenty i materialy [Yuri Tyutyunnyk: from «Dviika» to GPU: documents and materials]. Kyiv: DUKh I LITERA, 616 p. [in Ukrainian].

Volynske (1932). Volynske Ukrainske Teatralne Tovarystvo [Volyn Ukrainian Theater Society]. Ukrainska nyva, 3, 15 sichnia, 1. [in Ukrainian].

Haluzevyi derzhavnyi arkhiv sluzhby bezpeky Ukrainy, m. Kyiv. [Sectoral State Archive of the Security Service of Ukraine - SSA SSU, Kyiv].

Haluzevyi derzhavnyi arkhiv sluzhby bezpeky Ukrainy, m. Lutsk. [Sectoral State Archive of the Security Service of Ukraine-SSA SSU, Lutsk].

Haluzevyi derzhavnyi arkhiv Sluzhby zovnishnoi rozvidky Ukrainy [State Archive of the External Intelligence Service of Ukraine - SA EISU].

Davydiuk, R. (2016). Ukrainska politychna emihratsiia v Polshchi: sklad, struktura, hromadskopolitychni praktyky na terytorii Volynskoho voievodstva [Ukrainian Political Emigration in Poland: Staff, Composition, Structure, Socio-Political Practices in Volyn Region]. Lviv-Rivne: Diatlyk M., 704 p. [in Ukrainian].

Denysiuk, B. (2000). Serhii Kozytskyi [Serhiy Kozytskyi]. Ostrozki prosvitnyky XVI - XX st. (pp. 262-269). Ostroh, 2000. [in Ukrainian].

Derzhavnyi arkhiv Volynskoi oblasti [State Archive of Volyn Region-SAVR].

Derzhavnyi arkhiv Ivano-Frankivskoi oblasti [State Archives of Ivano-Frankivsk region-SAIFR]. Derzhavnyi arkhiv Rivnenskoi oblasti [State Archives of Rivne region-SARR].

Dilo (1925). Dilo [Dilo], 236, 22 zhovtnia, 2.

Zheplynskyi, B. Bilohub-Vernyhir Hanna Serhiivna [Bilohub-Vernyhir Hanna Serhiyivna]. Entsyklopediia suchasnoi Ukrainy. URL: http://esu.com.ua/search_articles.php?id=40776

Zhyviuk, A. (2011). Za moskovskym chasom: kontroversii radianizatsii Rivnenshchyny (kinets 1930-kh-kinets 1950-kh rokiv) [According to Moscow Time: the Controversies over the Sovietization of Rivne Region (the late 1930-ies - the late 1950-ies)]. Rivne: «Papirus-Druk», 186 p. [in Ukrainian].

Zahalni (1939). Zahalni zbory teatralnoho tovarystva [General Meeting of the Theater Society]. Volynske slovo, 4, 2 liutoho, 5. [in Ukrainian].

Konkurs (1934). Konkurs ukrainskykh Narodnykh khoriv u Volodymyri [Ukrainian Folk Choir Competition in Volodymyr]. Ukrainska nyva, 17, 22 travnia, 2. [in Ukrainian].

Kramar, Yu. (2015). Zakhidna Volyn 1921 - 1939 rr.: natsionalno-kulturne ta relihiine zhyttia [Western Volyn 1921-1939: National, Cultural and Religious Life]. Lutsk: Vezha-Druk, 404 p. [in Ukrainian].

Kursy (1930). Kursy instsenizatsii narodnoi pisni [Courses of Enactment of Folk Song]. Ukrainska nyva, 7, 14 liutoho, 4.

Lukaniuk, B. (ed.). (2015). Konkurs na volynski narodni pisni v 1934/35 navchalnomu rotsi. Vybrane [Competition on Volyn Folk Songs in the 1934/35 Academic Year. Selected]. Rivne, 20 p. [in Ukrainian].

Nykytiuk, N. (2008). Rol zhinotstva v muzychnii kulturi Volyni 20 -30-kh rr. XX st. [Role of Womanhood in Musical Culture of Volyn in the $20-30$-ies of the XXth century]. Studii mystetstvoznavchi, Kyiv: IMFE NAN Ukrainy, 2, 49-60. [in Ukrainian].

Ridna (1934). «Ridna Khata» V Lutsku [«Ridna Khata» in Lutsk]. Ukrainska nyva, 12-13, 8 kvitnia, 6. [in Ukrainian].

Samoorhanizatsiia (1926). Samoorhanizatsiia ta hromadske zhyttia ukrainskoi emihratsii v Polshchi (druha polovyna 1925 r. - 1 veresnia 1926 r.) [Self-organization and Public Life of Ukrainian Emigration in Poland (the second half of 1925 - September 1, 1926)]. Visti UTsK v Polshchi, 7, Hruden, 14-15. [in Ukrainian].

Soliar, I. (2009). Radianofilstvo u Zakhidnii Ukraini [Soviet Philosophy (Radyanophilstvo) in Western Ukraine]. Ukrainskyi istorychnyi zhurnal, 1, 55-67. [in Ukrainian].

Stoliarchuk, B. (2002). Nevidomi storinky folklorysta Serhiia Kozytskoho [Unknown Pages of Folklorist Serhiy Kozytskyi]. Naukovi zapysky Ternopilskoho derzhavnoho pedahohichnoho universytetu im. V. Hnatiuka. Seriia: Mystetstvoznavstvo, 1. 91-94. [in Ukrainian]. 
Teatralne (1939). Teatralne tovarystvo v Lutsku [Theater Society in Lutsk]. Volynske slovo, 6, 26 liutoho, 2. [in Ukrainian].

Ukrainska (1934). Ukrainska nyva [Ukrainian Field (Nyva)], 18, 2 chervnia, 4. [in Ukrainian].

Ukrainska (1927). Ukrainska nyva [Ukrainian Field (Nyva)], 75, 25 hrudnia, 3. [in Ukrainian].

Ukrainskyi (1927). Ukrainskyi Natsionalnyi Khor [Ukrainian National Choir]. Dilo, 217, 30 veresnia, 3. [in Ukrainian].

Ukrainski (1931). Ukrainski Narodni Khory VUO. Instruktsiia-rehuliamin [Ukrainian Folk Choirs of VUO. Instruction-Regulin]. Ukrainska nyva [Ukrainian Field (Nyva)], 34, 15 lystopada, 4. [in Ukrainian].

Filiia (1932). Filiia Teatralnoho T-va v Ostrozi [Branch of Theater Society in Ostroh]. Ukrainska nyva [Ukrainian Field (Nyva)], 40, 5 zhovtnia, 4. [in Ukrainian].

Shymanskyi, P. (2005). Muzychna kultura Volyni I pol. XX st. [Musical Culture of Volyn during the Ist half of the XXth century]. Lutsk: RVV «Vezha», 172 p. [in Ukrainian].

Wiszka, E. (2004). Emigracja ukraińska w Polsce 1920 - 1939 [Ukrainian Emigration in Poland in 1920 - 1939]. Toruń: MADO, 752 p. [in Poland].

The article was received on March 18, 2019. Article recommended for publishing 27/08/2019. 